\title{
Сергій Лукін
}

Заклад післядипломної освіти «Центр перепідготовки та підвищення кваліфікації працівників органів державної влади, органів місцевого самоврядування, державних підприємств, установ і організацій при Київській обласній державній адміністрації»

\section{Сучасні аспекти цифровізації публічних просторів}

У сучасному світі стрімко розвивається інформаційне суспільство. На думку більшості дослідників, йому притаманні такі фундаментальні риси: зростання інформаційної активності всіх членів суспільства, перетворення інформаційної індустрії в динамічну сферу його функціонування, проникнення інформаційно-комунікативних технологій у життєдіяльність кожної окремої людини, а також, завдяки широкому розповсюдженню гнучких мережевих структур, зміна всіх моделей соціальної організації і співпраці. В інформаційному суспільстві технології мас-медіа відіграють у житті людей вирішальну роль, особливо в процесах соціалізації, їх участі в суспільному житті. Газети, радіо і телебачення багато в чому стають інструментами державної інформаційної політики або відкритої пропаганди, то існування алгоритмічних корпорацій та їх незалежність від прямого державного регулювання підтримується активністю та якістю взаємодії самих користувачів. Багато держав проводять активну державну інформаційну політику, спрямовану на посилення правил поведінки у віртуальній публічній сфері, проте публічний простір у цих умовах має можливість зберігати свій критичний потенціал і дискусійний характер навіть в умовах маніпуляцій з боку держави.

Ключові слова: публічний простір, иифровізаиія, віртуальний публічний простір, комунікаиія, віртуалізаиія

\section{Modern aspects of digitalization of public spaces}

\section{Sergiy Lukin, Postgraduate Education Institution "Center for retraining and advanced training of} employees of public authorities, local governments, state enterprises, institutions and organizations under the Kyiv Regional State Administration"

In the modern world, the information society is developing rapidly. According to most researchers, it has the following fundamental features: the growth of information activity of all members of society, the transformation of the information industry into a dynamic sphere of its operation, the penetration of information and communication technologies in the life of each individual, and, thanks to widespread network structures, change all models of social organization and cooperation. In the information society, mass media technologies play a crucial role in people's lives, especially in the processes of socialization, their participation in public life. Newspapers, radio and television largely become tools of state information policy or open propaganda, the existence of algorithmic corporations and their independence from direct state regulation is supported by the activity and quality of interaction of users themselves. Many states pursue an active state information policy aimed at strengthening the rules of conduct in the virtual public sphere, but the public space in these conditions has the opportunity to maintain its critical potential and debatable nature, even in conditions of state manipulation.

Keywords: space, digitalization, virtual public space, communication, virtualization

Виклад основного матеріалу.

$\mathrm{P}$ озвиток сучасного суспільства характеризується глобалізацією та еволюцією інформаційно-комунікаційних технологій, яке супроводжується змінами наявних структур суспільства і виникненням нових соціальних феноменів.

Глобалізація розуміється як новий етап суспільного розвитку, який є поширенням взаємозалежності між країнами в економічній, політичній і культурній сфеpax; історичний процес зближення націй i народів, між якими поступово стираються міждержавні кордони і людство починає усвідомлювати свою цілісність. Глобалізації притаманні інтернаціоналізація, лібералізація, універсалізація, модернізація, детериторізація, а на сучасному етапі доповнено ще однією характеристикою - цифровізацією, що характеризується волею сучасного суспільства до віртуальної комунікації, зміни форм і стилю суспільновладних взаємовідносин, що обумовлює включення державно-управлінських структур у віртуальне середовище та зміну форм управління, зокрема впровадження онлайн платформ життєдіяльності громад. 
В умовах тотальної цифровізації суспільства та трансформації системи представництва громадських інтересів у сферу публічного масштабно проникають різноманітні соціальні медіа, публічний простір по суті перетворюється на суцільний медіа-процес, де громадянам представляється світ віртуального простору, гіперреальність та інші новітні механізми.

Віртуальний публічний простір надає розмах для інтелектуальної дискусії і суспільного діалогу, який відчуває дефіцит у сфері розробки адекватного алгоритму структурування та аналізу кіберактивності користувачів. Крім того, алгоритмічні пошукові системи, наприклад, Google, Baidu та інші самі $є$ корпоративними продуктами і товарами, які просуваються однойменними корпораціями (Xiong).

Серед сучасних дискусій щодо віртуальної публічної сфери можна виокремити щодо неї два найбільш вірогідних виклики, пов'язані зі спотворенням культури і стисненням простору критичної дискусії: 1) посилення контролю над Інтернет-простором за моделлю тоталітарної антиутопії Дж. Орвелла, у межах якої людина позбавлена альтернативних джерел інформації і живе в постійному страху (Orwell, 1949); 2) розвиток розважальної та споживчої продукції культури по моделі О. Хакслі, у межах якої суспільству загрожує не загальний контроль держави, а витіснення розважальним контентом будь-якої раціональної дискусії на периферію громадянського суспільства (Huxley, 1932).

Можливість користувачів брати участь у створенні культурного продукту у віртуальній публічній сфері найбільш очевидно проявляється у співпраці, обміні інформацією та досвідом, розвитку колективного інтелекту, що виражається на прикладі створення контенту для Інтернет-форумів, віртуальних енциклопедій, місць для розміщення відеофайлів і т. п. Крім того, найбільші світові пошукові системи, наприклад, Google - у глобальному масштабі і Baidu - у Східній Азії, стали віртуальними центрами громадянського суспільства і основою функціонування віртуальної публічної сфери.

Сучасні дослідження орієнтовані на вивчення таких соціально-філософських і соціо92 логічних аспектів віртуального середовища: збереження культурної самобутності та ідентичності; зміна систем соціальної комунікації; зміна соціальних інститутів; виникнення віртуальних спільнот, їх розвиток і взаємодія 3 традиційними спільнотами; трансформація сучасної економіки, політики, освіти та ін. При цьому як основні й найважливіші властивості віртуальної реальності виокремлюються породження, актуальність, автономність, інтерактивність, симулятивність, можливість впливу на події (Бодрійяр, Жижек та ін.) (Штанько, 2012, с. 7).

В. В. Афанасьєва у своєму дослідженні стверджує про появу глобального віртуального простору, який можна охарактеризувати такими властивостями: простір локалізовано в ноосфері; простір є транслятором основних типів віртуальних взаємодій, саме в ньому переміщуються основні віртуальні потоки: комунікативний, інформаційний, науковий і розважальний; простір є сховищем усіх віртуальних об'єктів, що створюється глобальною комп'ютерною мережею; простір з нетривіальною топологією, вимірність якого не визначена, динамічно змінна, фрактальна (Афанасьева, 2005, с. 69).

Віртуальний публічний простір можна розглядати як середовище, створене комп'ютерними технологіями, яке створює аудіовізуальну реальність публічного простору, що дозволяє людям взаємодіяти між собою і $з$ представленими в ньому об'єктами, яке містить організаційно-методичні умови та сукупність технічних і програмних засобів зберігання, обробки, передавання інформацiï.

На сьогодні особливостями функціонування віртуального публічного простору є:

- медіатизація, яка визначається сукупністю масових явищ інформаційного впливу і взаємодії. Медіатизація на перший план виводить не реальні дії і смисли, а віртуальну боротьбу за уми представників суспільства, при цьому засоби масової інформації виступають як інструменти управління соціально-політичною реальністю для переважної більшості людей;

- масова комунікація - найважливіший інструмент формування і самопрезентації віртуального публічного простору. На думку 
Л. Ніковської і В. Якимця, публічна сфера на сьогодні перетворюється на своєрідний «інноваційний інкубатор» нових соціально-комунікаційних практик, що дає змогу: «оптимізувати механізм взаємодії держави, бізнесу та громадянського суспільства (розвивати міжсекторне соціальне партнерство); долати 3 метою конструктивного реформування закостенілість державних інститутів; підключати ресурс громадських ініціатив до формування державної політики та контролю за діяльністю влади» (Никовская, Якимец, \& Молокова, 2011, с. 135);

- використання практик електронної демократії. Це можливості нових електронних медіа поліпшити інфраструктуру демократичного суспільства, створюючи умови переходу від представницької до демократії участі, від участі однієї особи до співучасті всіх громадян у вирішенні актуальних соціальних проблем разом 3 владними органами за допомогою проведення інтерактивних діалогів, форумів, телеконференцій і телеголосування. Важливими принципами електронної демократії є прозорість, участь, відкритість. Електронна демократія $\epsilon$ інструментом для соціальної інтеграції, соціалізації, громадянської освіти, обміну знаннями. На сьогодні прикладами механізмів електронної демократії у віртуальному публічному просторі можна виокремити мережеве спілкування громадян і колективне обговорення нагальних питань у режимі онлайн (е-петиції, е-звернення), формування онлайн-спільнот (онлайн-ком'юніті), планування та реалізації громадських ініціатив та різноманітних проектів;

- використання smart-технологій. Інформаційні технології змінюються сучасними smart-технологіями, які визначають функ- ціональну спрямованість інформаційних процесів у віртуальному публічному просторі. Переваги таких технологій відзначаються широким діапазоном використання: у високорозвинутих країнах smart-технології ефективно використовують у багатьох сфеpax: культурі, освіті, економіці тощо. Ефективність smart-технологій характеризується такими чинниками: мобільний доступ (отримання широкого спектру послуг у будь-якій точці світу); нагромадженням і систематизацією отриманої інформації у вигляді нових знань; формуванням smart-оточення, при якому інформаційно-технологічне середовище наближається до природного інтелекту, стимулюючи появу подібних розробок i слугуючи основою для авторських розробок.

Висновки. Розвиток віртуальної сфери сприяє становленню різноманіття форм i методів комунікації учасників, презентуючи більш досконалі і ефективні інструменти взаємодії та впливу їх один на одного. У той же час Інтернет стимулює інтенсифікацію комунікаційних процесів, що є результатом стрімкого проникнення комп'ютерних технологій в усі сфери життя суспільства. Таким чином, віртуальний публічний простір, формуючи нові можливості і реалії комунікацій, стає найбільш динамічним технологічним, а на сьогодні й економічним, культурним, соціальним і політичним феноменом сучасності. Однак через стрімкий прогрес інноваційних та інформаційно-технологічних технологій та трансформаційні зміни, які відбуваються за результатами цього, поняття віртуального публічного простору потребує постійного дослідження відповідно до вимог часу.

\section{БІБЛІОГРАФІЧНІ ПОСИЛАННЯ}

Афанасьева, В. В. (2005). Тотальность виртуального: монография. Научная книга. Саратов: Издательство Саратовского университета.

Никовская, Л., Якимец, В. Н., Молокова, М. А. (2011). Гражданские инициативы и модернизация. Гражданские инициативы и модернизация. Москва: Ключ-С.

Штанько, В. І. (2012). Віртуальний комунікативний простір і проблеми самоідентифікації особистості. Вісник Харківського національного університету імені В. Н. Каразіна. Серія: Теорія культури і філософія науки, 1029(1), 5-12.

Huxley, A. (1932). Brave New World. London: Chatto and Windus.

Orwell, G. (1949). Nineteen Eighty-Four. London: Secker \& Warburg.

Xiong, Y. Public Sphere 3.0: Algorithmic Corporation's 21st Century Civil Society Global Renaissance. Retrieved from http://www.academia.edu/25033107/Public_Sphere_3.0_Algorithmic_Corporations_21st_Century_Civil_ Society_Global_Renaissance/. 